\title{
A Research on Work Life Balance of Employees Aruneshwara Hi-Tech in in Thiruvanamalai
}

\author{
Magdalene Peter, S.Fabiyola Kavitha
}

\begin{abstract}
Work Life balance of an Employee is very important for any Organisation. Proper balance of Work and Life will automatically lead to higher yield. This Work Life Balance is a sensitive issue and there are many factors which ultimately lead to proper balance of Professional Work and Personal Life. These factors can be segregated as Demographic and Psychographic. The challenge is to find out the extent of impact of these two variables on the Work Life balance of an Employee and meet him at the point of his need. The below study is an analysis of the Work Life Balance of Employees working in Arunsehwara Hi-Tech in Thiruvannamalai.
\end{abstract}

\section{INTRODUCTION}

VST Tillers \& Tractors Limited (VTTL), is a company formed on account of a JV between VST group and Mitsubishi Heavy Industries in 1967. VTTL derives its major income from manufacturing and marketing two agricultural aid equipments i.e. Power tillers and Tractors. It also trades in reapers, rice transplanters and other spare components. Company is a market leader in the power tiller segment across country deriving major income from the agriculture activities in South India and is a fast growing company in the sub-30 HP tractor segment.

\section{RESEARCH METHODOLOGY}

\section{OBJECTIVES OF THE STUDY}

\section{PRIMARY OBJECTIVES}

\section{TO STUDY ON WORK LIFE BALANCE OF EMPLOYEES IN ARUNESHWARA HI-TECH}

\section{SECONDARY OBJECTIVES}

- To study how the impact of Family influences the Stress generated through Work.

- To study if Employees are able to manage Timefor personal and Professional Commitment.

- To study if length of Working Hours has a bearing on Professional Productivity

- To study if employee health reflects the output

- To study about Prioritisation of Employee

Revised Manuscript Received on 30 July 2019.

* Correspondence Author

Magdalene Peter*, Assistant Professor, Department of Management Studies, BIHER. (E-mail: magdalene.bsb@gmail.com) Ph: 9940655183.

Dr.S.Fabiyola Kavitha, Associate Professor, SRM, Trichy.

(C) The Authors. Published by Blue Eyes Intelligence Engineering and Sciences Publication (BEIESP). This is an open access article under the CC-BY-NC-ND license http://creativecommons.org/licenses/by-nc-nd/4.0/

\section{RESEARCH DESIGN}

Descriptive Research Design is followed in this article.

II.

METHODS OF DATA COLLECTION

Primary Sources

1. Data are collected through personal interviews and discussion with

HR Executive.

2. Data are collected through personal interviews and discussion with Material

Planning- Deputy Manager.

Secondary Sources

1. Data are collected from the company's website.

2. Books and journals pertaining to the topic.

\section{SAMPLING METHOD}

Simple Random sampling

Random sampling being adopted in this study.

Systematic sampling:

SAMPLE SIZE:

The sample size 112 respondents.

\section{STATISTICAL TOOLS USED}

This research has used the following statistical tools

- Simple Percentage Analysis

Frequency Analysis

\section{LIMITATIONS OF STUDY}

- The sample size is limited so I cannot provide all employees opinion

- Do not have an extensive experience in primary data collection

- Take some time to understand the company and employees attitude in organisation environment

DATA ANALYSIS AND INTERPRETATION

TABLE 1: MORE THAN 6 DAYS IN A WEEK

\begin{tabular}{|l|l|l|}
\hline PARTICULARS & $\begin{array}{l}\text { NO } \\
\text { RESPONDENT }\end{array}$ & PERCENTAGE \\
\hline ALWAYS & 30 & 24.7 \\
\hline OFTEN & 5 & 4.1 \\
\hline
\end{tabular}




\begin{tabular}{|l|l|l|}
\hline SOMETIMES & 17 & 14.04 \\
\hline RARELY & 57 & 47.10 \\
\hline NEVER & 3 & 2.47 \\
\hline TOTAL & $\mathbf{1 1 2}$ & $\mathbf{1 0 0}$ \\
\hline
\end{tabular}

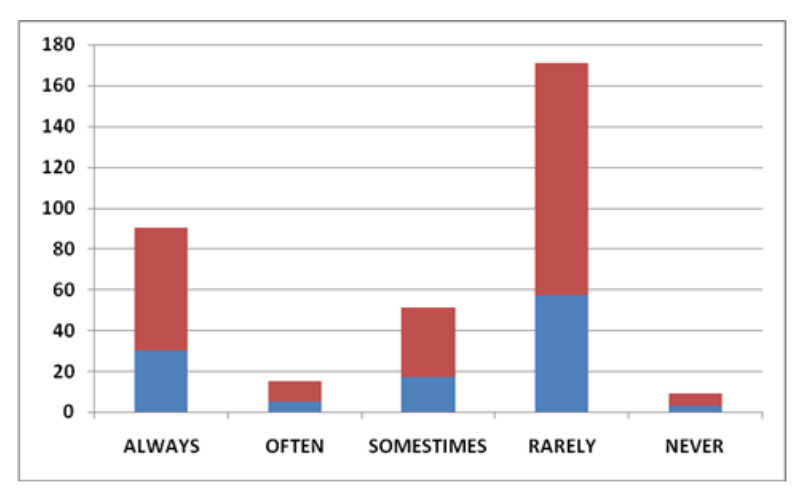

III. INTERPRETATION:

In this table 1 shows more than 6days employees working so rarely is highest because most of the employees finish their work with the working days.

TABLE 2: MORE THAN 12 HRS WORKING IN A DAY

\begin{tabular}{|l|l|l|}
\hline PARTICULARS & $\begin{array}{l}\text { NO OF } \\
\text { RESPONDENT }\end{array}$ & PERCENTAGE \\
\hline ALWAYS & 10 & 8.26 \\
\hline OFTEN & 10 & 24.2 \\
\hline SOMETIMES & 5 & 8.26 \\
\hline RARELY & 20 & 16.5 \\
\hline NEVER & 67 & 55.3 \\
\hline TOTAL & $\mathbf{1 1 2}$ & $\mathbf{2 2 4}$ \\
\hline
\end{tabular}

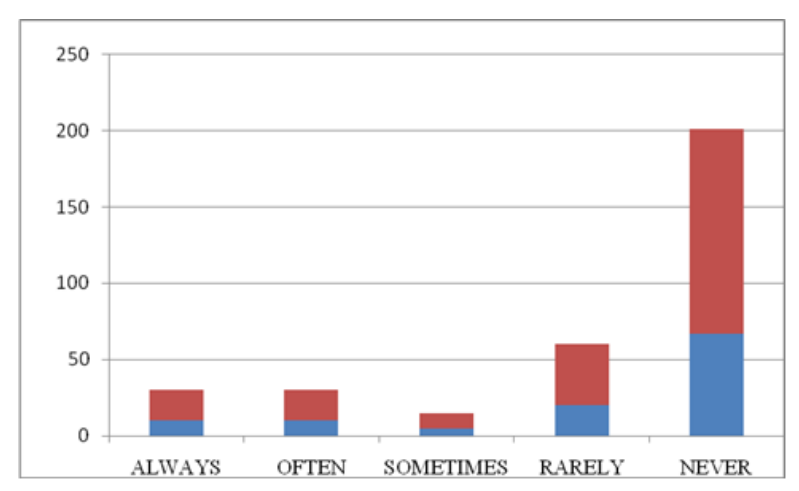

\section{INTERPRETATION:}

In this table 2 shows more than $12 \mathrm{hrs}$ employees not working more so rarely is highest because most of the employees finish their work with the working time..

TABLE NO 3: EMPLOYEE FEEL NOT ABLE TO BALANCE THEIR WORKLIFE

\begin{tabular}{|l|l|l|}
\hline PARTICULARS & $\begin{array}{l}\text { NO OF } \\
\text { RESPONDENT }\end{array}$ & PERCENTAGE \\
\hline ALWAYS & 20 & 16.5 \\
\hline OFTEN & 22 & 18.1 \\
\hline SOMETIMES & 10 & 8.26 \\
\hline RARELY & 20 & 16.5 \\
\hline NEVER & 40 & 33.0 \\
\hline TOTAL & $\mathbf{1 1 2}$ & $\mathbf{1 0 0}$ \\
\hline
\end{tabular}

Retrieval Number: B1064078219/19@BEIESP

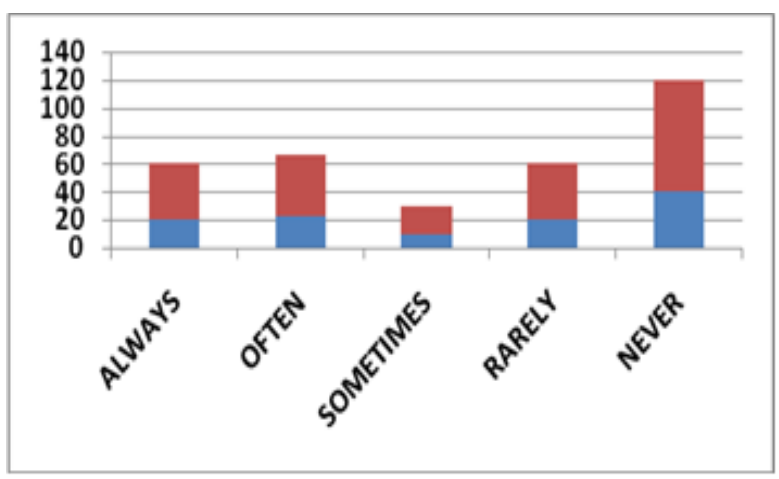

IV.

INTERPRETATION \& RESULTS

In this table shows employees can able their work life balance because in this company running with all the flexible times so employees are not feel they cannot able to balance their worklife

TABLE NO 4 EMPLOYEE THINK OR WORRY ABOUT WORK (WHEN YOU ARE NOT ACTUALLY AT WORK)

\begin{tabular}{|l|l|l|}
\hline PARTICULARS & $\begin{array}{l}\text { NO OF } \\
\text { RESPONDENT }\end{array}$ & PERCENTAGE \\
\hline ALWAYS & 13 & 15.7 \\
\hline OFTEN & 10 & 8.26 \\
\hline SOMETIMES & 18 & 14.8 \\
\hline RARELY & 35 & 28.9 \\
\hline NEVER & 36 & 29.7 \\
\hline TOTAL & $\mathbf{1 1 2}$ & $\mathbf{1 0 0}$ \\
\hline
\end{tabular}

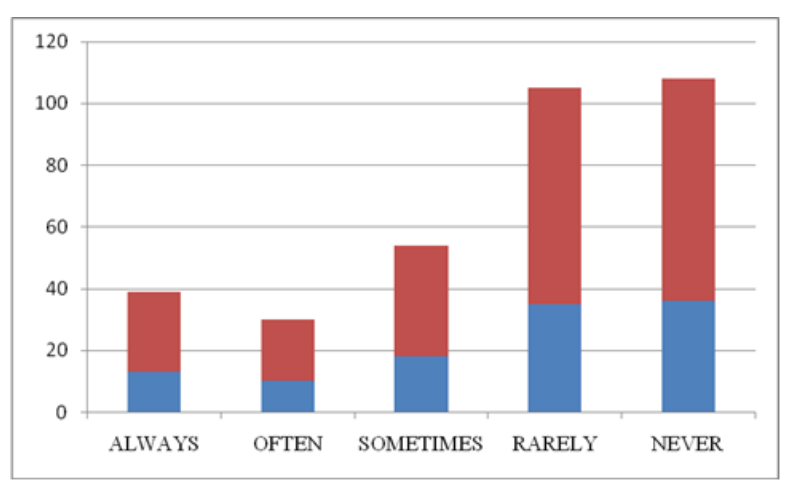

INTERPRETATION:

Most of the employees are worrying about their work rare time because when they have depressed or pressure work .

TABLE NO 5 EMPLOYEE WORK IN SHIFTS

\begin{tabular}{|l|l|l|}
\hline PARTICULARS & $\begin{array}{l}\text { NO OF } \\
\text { RESPONDENT }\end{array}$ & PERCENTAGE \\
\hline ALWAYS & 22 & 18.1 \\
\hline OFTEN & 25 & 20.66 \\
\hline SOMETIMES & 17 & 14.04 \\
\hline RARELY & 24 & 19.8 \\
\hline NEVER & 24 & 19.8 \\
\hline TOTAL & $\mathbf{1 1 2}$ & $\mathbf{1 0 0}$ \\
\hline
\end{tabular}

Published By: 


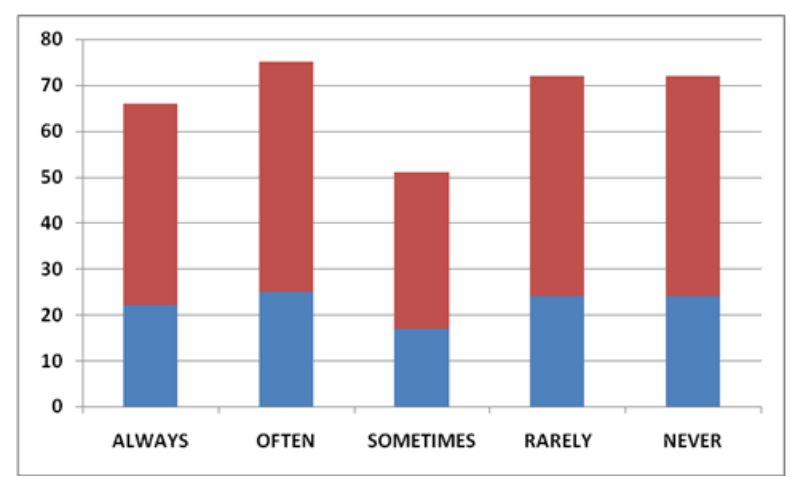

INTERPRETATION:

Some employees working shift based some employees rarly working shift based $19.8 \%$ equally.

TABLE NO 6 UNABLE TO SPEND TIME WITH YOUR FAMILY

\begin{tabular}{|l|l|l|}
\hline PARTICULARS & $\begin{array}{l}\text { NO OF } \\
\text { RESPONDENT }\end{array}$ & PERCENTAGE \\
\hline ALWAYS & 17 & 14.04 \\
\hline OFTEN & 22 & 18.1 \\
\hline SOMETIMES & 5 & 4.1 \\
\hline RARELY & 28 & 23.0 \\
\hline NEVER & 40 & 33.0 \\
\hline TOTAL & $\mathbf{1 1 2}$ & $\mathbf{1 0 0}$ \\
\hline
\end{tabular}

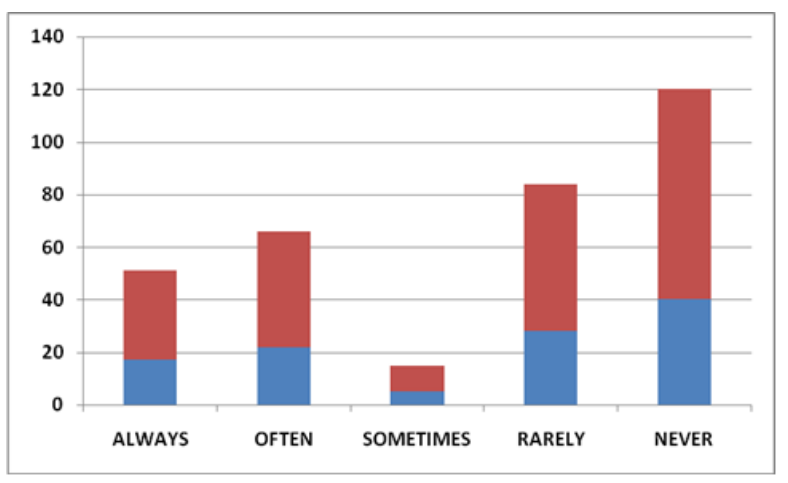

INTERPRETATION:

Most of the Employees are able to spend with family because the company give time to do work alternatively

TABLE NO 7 EVER FEEL TIRED OR DEPRESSED BECAUSE OF WORK

\begin{tabular}{|l|l|l|}
\hline PARTICULARS & $\begin{array}{l}\text { NO OF } \\
\text { RESPONDENT }\end{array}$ & PERCENTAGE \\
\hline ALWAYS & 14 & 11.57 \\
\hline OFTEN & 10 & 8.26 \\
\hline SOMETIMES & 7 & 5.7 \\
\hline RARELY & 18 & 14.8 \\
\hline NEVER & 63 & 52.0 \\
\hline TOTAL & $\mathbf{1 1 2}$ & $\mathbf{1 0 0}$ \\
\hline
\end{tabular}

\begin{tabular}{|l|l|l|}
\hline PARTICULARS & $\begin{array}{l}\text { NO OF } \\
\text { RESPONDENT }\end{array}$ & PERCENTAGE \\
\hline ALWAYS & 60 & 49.5 \\
\hline OFTEN & 17 & 14.0 \\
\hline SOMETIMES & 10 & 8.26 \\
\hline RARELY & 12 & 9.91 \\
\hline NEVER & 13 & 10.74 \\
\hline TOTAL & $\mathbf{1 1 2}$ & $\mathbf{1 0 0}$ \\
\hline
\end{tabular}

\begin{tabular}{|l|l|l|}
\hline PARTICULARS & $\begin{array}{l}\text { NO OF } \\
\text { RESPONDENT }\end{array}$ & PERCENTAGE \\
\hline ALWAYS & 8 & 6.6 \\
\hline OFTEN & 12 & 9.9 \\
\hline SOMETIMES & 35 & 28.9 \\
\hline RARELY & 35 & 28.9 \\
\hline NEVER & 22 & 18.1 \\
\hline TOTAL & $\mathbf{1 1 2}$ & $\mathbf{1 0 0}$ \\
\hline
\end{tabular}

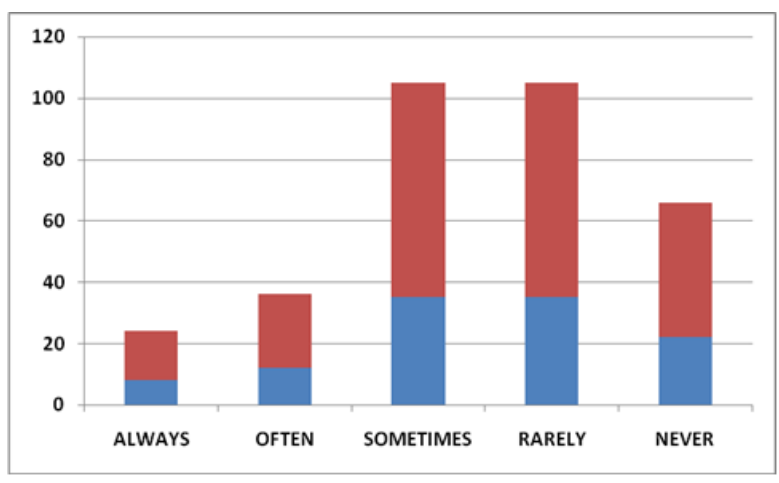

INTERPRETATION:

This company follow policy sometime is high $28.9 \%$ rarely is equal of $28.9 \%$ always is very low $6.6 \%$.

TABLE NO 9 IF EMPLOYEES HAVE GOOD WORKLIFE BALANCE THE ORGANIZATION WILL BE MORE EFFECTIVE AND SUCCESSFUL 


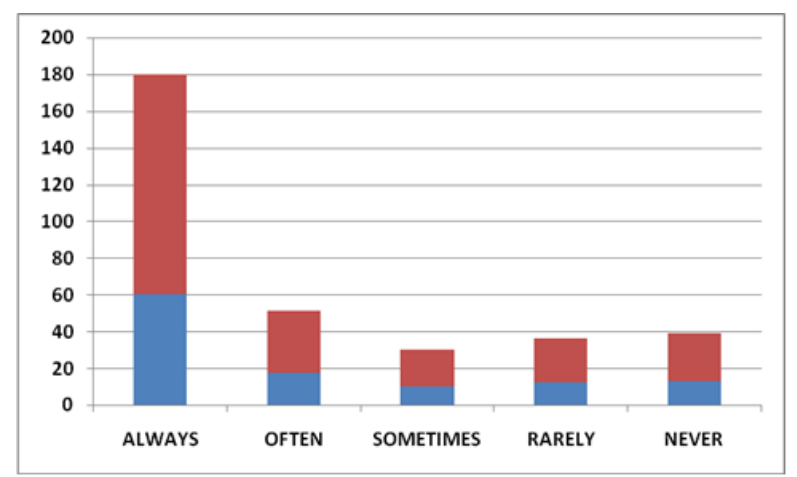

\section{INTERPRETATION:}

The employees agree good work-life balance the organization will be more effective and successful because the always option is highest $49.5 \%$ the lowest is sometimes $8.26 \%$.

\section{V. $\quad$ FINDINGS}

- More than 6 days in a week is 1 st table shows rarely is highest

- More than $12 \mathrm{hrs}$ employees not working more so rarely is highest because most of the employees finish their work with the working time.

- Employees can able their work life balance because in this company running with all the flexible times

- Most of the employees are worrying about their work rare time because when they have depressed or pressure work

- Some employees working shift based some employees rarly working shift based $19.8 \%$ equally.

- Most of the Employees are able to spend with family because the company give time to do work alternatively.

- This company follow policy sometime is high $28.9 \%$ rarely is equal of $28.9 \%$ always is very low $6.6 \%$.

\section{SUGGESTIONS}

- Protecting employees from long hours of work and Maintain the working days condition

- Expand the facilities for Childcare Centres at workplaces

- I suggest to develop the health check -up department to employees atlest conduct yearly health check-up

- Company takes care of the employees working in night shift concentrate on all employees

\section{CONCLUSION}

Personal and Professional Life balance is very important to maintain peace in life. This study is important because it helps to maintain harmony between two constructs of life which leads to high productivity. Nowadays, Organisations are waking up to the truth that Work Life balance is very important and spills over all aspects of Organisational and Personal Life. From this study, it is understood that employees working at Aruneshwara are well aware about the implications and the need of Work Life Balance.

\section{BIBLIOGRAPHY}

1. http://www.recentscientific.com/sites/default/files/2926.pdf

2. https://www.slideshare.net/SheetalJain9/questionnaire-onwork-life-balance-for-working-parents

3. http://www.iracst.org/ijrmt/papers/vol5no12015/6vol5no1.pdf

4. http://shodhganga.inflibnet.ac.in/bitstream/10603/37171/18/1 8_appendix.pdf

5. http://shodhganga.inflibnet.ac.in/bitstream/10603/5663/17/17 synopsis.pdf

6. http://www.academia.edu/4280265/WLB_Questionnaire

\section{BOOKS:}

- Do Less, Get More - by Shaa Wasmund

- The One Minute Manager Balances Work and Life by Ken Blanchard

- MICHAEL R. LOSEY, SPHR, CAE, is President of MikeLosey.com, as well as a former president of the Society for Human Resource Management and of the World Federation of Personnel Management Associations

- SUSAN MEISINGER, Esq., SPHR, is President and CEO of the Society for Human Resource Management, current Secretary General of the World Federation of Personnel Management Associations, and former Deputy Undersecretary of the U.S. Department of Labor.

- DAVE ULRICH, PhD, professor at the University of Michigan and renowned expert in management education, is the author of twelve books, including Why the Bottom Line Isn't!, also from Wiley. 